\title{
PENDUGAAN JARAK GENETIK POPULASI UDANG GALAH (Macrobrachium rosenbergii) DARI SUNGAI MUSI, SUNGAI KAPUAS, DAN SUNGAI CITANDUY DENGAN TRUSS MORPHOMETRIC UNTUK MENDUKUNG PROGRAM PEMULIAAN
}

\begin{abstract}
Wartono Hadie"), Komar Sumantadinata“), Odang Carman“), dan Lies Emmawati Hadie")
ABSTRAK

Indonesia mempunyai plasma nutfah udang galah yang tersebar dari Sumatera hingga Papua. Adaptasi lokal yang cukup panjang membuat ekspresi gen lokal menjadi kuat dan memperlihatkan karakter spesifik pada habitatnya. Studi truss morphometric pada udang galah dilakukan pada tiga populasi alami untuk mengevaluasi perbedaan morfometrik di antara populasi tersebut. Dari masing-masing populasi (Sungai Kapuas, Sungai Musi, dan Sungai Citanduy) diambil 50 ekor jantan dan 50 ekor betina untuk diukur komponen penting sebagai variabel pembedanya. Sepuluh titik homologus dan 21 truss distance diukur dan dianalisis. Hubungan kekerabatan yang didapat dari analisis diskriminan pada ketiga populasi tersebut dapat digunakan sebagai acuan dalam pelaksanaan persilangan intra spesifik. Jarak kekerabatan antara Kapuas-Citanduy adalah 16,557; Musi-Citanduy adalah 8,788; dan Musi-Kapuas adalah 3,970. Perkawinan antara Kapuas $x$ Citanduy akan menghasilkan efek heterosis yang lebih baik dibanding kombinasi lainnya.
\end{abstract}

ABSTRACT: Genetic distance assessment of freshwater prawn, Macrobrachium rosenbergii de Man, populations from Musi, Kapuas, and Citanduy rivers by truss morphometric to support its breeding program. By: Wartono Hadie, Komar Sumantadinata, Odang Carman, and Lies Emmawati Hadie

\begin{abstract}
The Indonesia archipelago has diverse Macrobrachium rosenbergii germ plasms which was wide separately distributed in Sumatra, Jawa, Kalimantan, Sulawesi, and the Papua. Long term local adaptation makes strength local gene expression. The aim of morphometric variation study of Macrobrachium rosenbergii populations in different localities in Indonesia was to determine their phenotypic differences. From each population, 50 male, and 50 females prawns were sampled. The samples were collected from Musi River, Kapuas River and Citanduy River. The 10 specific homologous points and 21 truss distances were measured. Principle component analysis (PCA) and discriminant analysis were used to analyze of morphometric variations among population. The relatedness assessment was done by discriminant analysis and principal component analysis from three natural populations. The values of relatedness were 16.557, 8.788, and 3.970 for Kapuas-Citanduy, Musi-Kapuas, and Musi-Kapuas, respectively. The best possible heterosis effect cross will be achieved between Kapuas $\times$ Citanduy or Musi $x$ Citanduy than Musi x Kapuas.
\end{abstract}

KEYWORDS: $\quad$ truss morphometric, population, Macrobrachium rosenbergii, PCA genetic distance

\section{PENDAHULUAN}

Variasi morfologi dapat dipertimbangkan sebagai indikator perbedaan genetik antar spesies, strain, jenis kelamin, atau populasi. Sebagai contoh bentuk badan ikan yang hidup di sungai dengan arus yang deras biasanya lebih pipih, sementara yang hidup di lingkungan budi daya atau lingkungan yang lebih baik, bentuknya lebih tebal (McGlade \& Boulding, 1985).

Pendekatan dengan ukuran komersial (panjang dan bobot badan) dan karakter meristik dapat digunakan untuk membedakan strain, jenis kelamin, stok, spesies hibrida, atau populasi telah dipakai untuk beberapa jenis ikan. Akan tetapi Truss morphometric adalah suatu teknik yang lebih baik untuk membedakan bentuk tubuh pada populasi ikan. Pengukuran truss digunakan oleh Strauss (1980) untuk menganalisis variasi geografis dari Sculfin air tawar dan dengan jelas menemukan perbedaan pada morfologi antar sampel dari Danau Coyaga dan Ontario. Sementara Cataudelia (1987) mengamati karakter ikan mas dengan menggunakan truss dan pengukuran konvensional, dan menyimpulkan bahwa truss memberikan hasil yang lebih baik dibanding dengan metode konvensional (Hadie, 1997).

\footnotetext{
Peneliti pada Balai Penelitian Perikanan Air Tawar, Sukamandi Dosen Fakultas Perikanan dan IImu Kelautan IPB, Bogor
} 
Beberapa ukuran morfometrik pada udang galah hanya terbatas pada ukuran karkas dan ukuran komersial (Malecha et al., 1982). Oleh karena itu adopsi metode yang dikembangkan pada ikan dapat dilakukan untuk udang galah dengan memperhatikan komponen penting bentuk morfologinya.

Bookstein et al. (1985) mengembangkan ukuran truss morphometric dan menunjukkan bahwa ukuran ini meningkatkan kemampuan untuk membedakan bentuk intraspesifik. Pada truss morphometric ditetapkan seperangkat ukuran, termasuk pemilihan garis (titik homolog) sepanjang garis luar badan ikan.

Perbedaan morfologis antar populasi dapat berupa perbedaan seluruh ukuran atau bentuk, tetapi secara umum cenderung melibatkan keduanya (Sprent, 1972). Perbedaan bentuk antar populasi ikan dinyatakan sebagai fungsi ukuran (McGlade \& Boulding, 1985); oleh karena itu perbandingan ukuran tidak boleh diabaikan, bahkan merupakan bagian dari analisis (Humphries et al., 1981).

Karakterisasi morfometrik dari strain spesies yang sama mencakup penentuan perbedaan yang kecil dalam variasi bentuk dan ukuran. Kebiasaan pengukuran secara tradisional (panjang standar, panjang badan, panjang total, dan lain-lain) cenderung mendapatkan ukuran yang tertumpu pada satu daerah tertentu. Hal ini menyebabkan metode truss morphometric menjadi teknik pengukuran yang dianjurkan karena akan menghasilkan bentuk tubuh dalam populasi yang sebenarnya (Eknath et al., 1991).

Tujuan penelitian adalah untuk mengidentifikasi jarak genetik (hubungan kekerabatan) berdasarkan karakter morfologis dengan truss morphometric dari 3 populasi udang galah yang berasal dari Sungai Kapuas, Sungai Musi, dan Sungai Citanduy.

\section{BAHAN DAN METODE}

Sampel udang galah yang digunakan diambil dari 3 daerah yang terpisah (masing-masing adalah Sungai

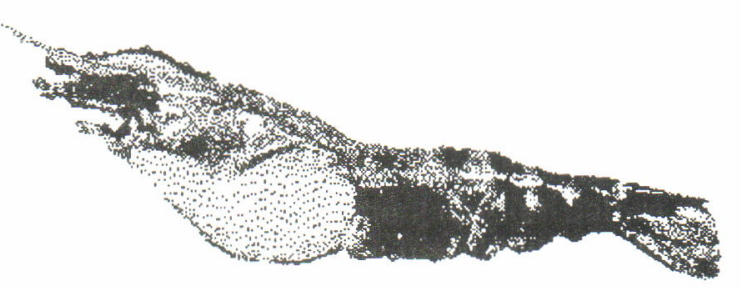

Kapuas, Sungai Musi, dan Sungai Citanduy). Sampel diawetkan dengan alkohol dan masing-masing populasi diamati sebanyak 50 ekor jantan dan 50 ekor betina. Parameter morfometrik yang digunakan dalam analisis data meliputi 4 truss cell 21 truss distance (Gambar 1).

Lokasi (sungai) digunakan sebagai peubah kelompok udang galah. Fungsi diskriminan sederhana dilakukan untuk penentuan jarak genetik (Bookstein, et al., 1985). Matrik dikelompokkan ke dalam ragam peragam antara peubah di antara populasi yang didapat dari jarak mahalanobis. Kunci parameter yang diamati dari karakter morfometrik dapat dilihat pada Tabel 1.

Jarak kuadrat genetik minimum digunakan rumus Manly (1989) dan Nei (1987) dalam Suparyanto et al. (1999):

$$
D_{(i, j)}^{2}=\left(X_{i}-X_{j}\right) C^{-1}\left(X_{i}-X_{j}\right)
$$

dengan:

$D_{(i, j)}^{2}=$ nilai statistik mahalanobis sebagai ukuran jarak kuadrat genetik antar dua populasi

$\mathrm{C}^{-1}=$ kebalikan matrik gabungan ragam peragam antar peubah

$X=$ vektor nilai rataan pengamatan dari populasi i pada masing-masing peubah

$X_{j}=$ vektor nilai rataan pengamatan dari populasi jpada masing-masing peubah

Untuk membantu analisis mahalanobis digunakan program SAS versi 6.12 dengan menggunakan PROC DISCRIM (Suparyanto et al., 1999). Jarak kuadrat yang dihasilkan kemudian diakarkan.

Untuk mendapatkan peta penyebaran populasi dan nilai kesamaan di dalam dan di luar kelompok digunakan analisis diskriminan (PCA) menggunakan SPSS 10.0. Komponen ini juga digunakan untuk melihat pengaruh yang paling kuat terhadap pembentukan kelompok populasi.

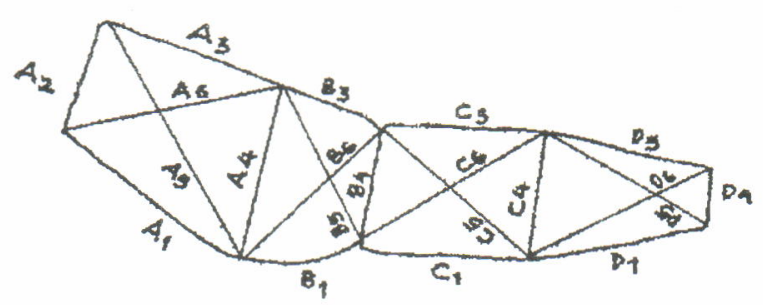

Gambar 1. Variabel ukuran truss morphometrik (menunjukkan titik homologus, truss cell, dan truss distance) yang digunakan dalam analisis jarak genetik udang galah. Setiap truss cell $(A, B, C, D)$ terdiri atas 6 truss distance (A1, A2, A3, A4, A5, A6, dan seterusnya).

Figure 1. Variable of truss morphometric measurement (showed the homologous point, truss cell, and truss distance) that used in genetic analysis of giant freshwater prawn. Each of truss cell $(A, B, C$, and $D)$ have 6 truss distance $(A 1, A 2, A 3, A 4, A 5, A 6, B 1$, etc.). 
Tabel 1. Kunci parameter yang diamati pada pengukuran truss morphometric udang galah

Table 1. Principle parameters observed on truss morphometric measurement of truss morphometric of giant freshwater prawn

\begin{tabular}{|c|c|c|}
\hline $\begin{array}{l}\text { Simbol } \\
\text { Symbol }\end{array}$ & $\begin{array}{c}\text { Ukuran truss } \\
\text { Truss measurement }\end{array}$ & $\begin{array}{c}\text { Karakter morfometris } \\
\text { Morphometric characters }\end{array}$ \\
\hline A1 & Bagian terlebar dari kepala ventral - bawah tangkai mata & \\
\hline A2 & $\begin{array}{l}\text { Jarak vertikal antara bagian bawah tangkai mata - } \\
\text { pangkal rostrum }\end{array}$ & Lebar kepala depan \\
\hline A3 & Jarak antara pangkal rostrum - pertengahan kepala & \\
\hline A4 & Jarak vertikal bagian terlebar dari kepala & \\
\hline A5 & $\begin{array}{l}\text { Diagonal bagian terlebar kepala ventral - } \\
\text { pangkal rostrum }\end{array}$ & \\
\hline A6 & $\begin{array}{l}\text { Diagonal bagian terlebar kepala dorsal - bawah } \\
\text { tangkai mata }\end{array}$ & Bagian kepala terlebar \\
\hline B1 & $\begin{array}{l}\text { Batas belakang kepala ventral - bagian terlebar } \\
\text { kepala ventral }\end{array}$ & \\
\hline B3 & $\begin{array}{l}\text { Pertengahan kepala terlebar dorsal - batas belakang } \\
\text { kepala dorsal }\end{array}$ & \\
\hline B4 & $\begin{array}{l}\text { Jarak vertikal batas belakang kepala dorsal - } \\
\text { bagian ventral }\end{array}$ & \\
\hline B5 & $\begin{array}{l}\text { Diagonal batas belakang kepala ventral - pertengahan } \\
\text { kepala dorsal }\end{array}$ & \\
\hline B6 & $\begin{array}{l}\text { Diagonal batas belakang kepala dorsal - pertengahan } \\
\text { kepala ventral }\end{array}$ & Lebar kepala belakang \\
\hline $\mathrm{C} 1$ & $\begin{array}{l}\text { Batas belakang ruas } 3 \text { abdomen ventral - batas } \\
\text { depan ruas } 1 \text { abdomen ventral }\end{array}$ & \\
\hline C3 & $\begin{array}{l}\text { Batas depan ruas } 1 \text { abdomen dorsal - batas } \\
\text { belakang ruas } 3 \text { abdomen dorsal }\end{array}$ & \\
\hline $\mathrm{C4}$ & Jarak vertikal batas belakang ruas 3 dorsal - ventral & \\
\hline $\mathrm{C5}$ & Diagonal bagian belakang ruas 3 ventral - ruas 1 dorsal & \\
\hline C6 & Diagonal bagian belakang ruas 3 dorsal - ruas 1 ventral & Bagian badan terlebar \\
\hline D1 & $\begin{array}{l}\text { Jarak batas belakang ruas } 6 \text { abdomen ventral - bagian } \\
\text { depan ruas } 4 \text { ventral }\end{array}$ & \\
\hline D3 & $\begin{array}{l}\text { Jarak batas depan ruas } 4 \text { abdomen dorsal - bagian } \\
\text { belakang ruas } 6 \text { dorsal }\end{array}$ & \\
\hline D4 & Jarak vertikal bagian belakang ruas 6 dorsal - ventral & \\
\hline D5 & $\begin{array}{l}\text { Diagonal batas belakang ruas } 6 \text { ventral - batas } \\
\text { depan ruas } 4 \text { dorsal }\end{array}$ & Tinggi badan bagian belakang \\
\hline D6 & $\begin{array}{l}\text { Diagonal batas belakang ruas } 6 \text { dorsal - batas } \\
\text { depan ruas } 4 \text { ventral }\end{array}$ & \\
\hline
\end{tabular}

\section{HASIL DAN BAHASAN}

Hasil analisis diskriminan (Tabel 2) merupakan rataan sifat (trait) antar lokasi yang telah direlatifkan terhadap panjang standar (PS). Hal ini dilakukan untuk menghindari keragaman ukuran dan kemungkinan umur yang berbeda. Tujuannya adalah untuk memperkecil kesalahan terutama terhadap hewan yang pertumbuhannya tidak proporsional (Matricia, 1990).
Dari tabel tersebut terlihat ada beberapa komponen umum yang ditunjukkan dengan tidak adanya beda nyata $(P>0,05)$ antar populasi, komponen tersebut dapat dianggap sebagai conserved gene. Sementara itu beberapa komponen tertentu terjadi pertumbuhan yang spesifik pada masing-masing habitat atau populasi yang ditunjukkan dengan perbedaan yang sangat nyata $(P<0,01)$ di antara populasi yaitu pada komponen $\mathrm{A} 3, \mathrm{A4}, \mathrm{B} 3, \mathrm{~B} 4, \mathrm{C} 1$, dan $\mathrm{D} 1$. 
Tabel 2. Komponen morfometrik sampel populasi udang galah, dengan analisis Canonical Discriminant Univariate Test Statistics

Table 2. The component sample of giant freshwater prawn populations analized by Canonical Discriminant Univariate Test Statistics

\begin{tabular}{|c|c|c|c|c|c|c|c|}
\hline $\begin{array}{l}\text { Variabel } \\
\text { Variable }\end{array}$ & $\begin{array}{c}\text { Total } \\
\text { STD }\end{array}$ & $\begin{array}{c}\text { Pooled } \\
\text { STD }\end{array}$ & $\begin{array}{c}\text { Between } \\
\text { STD }\end{array}$ & R-Squared & $\begin{array}{c}\text { RSQ } \\
\text { (1-RSQ) } \\
\end{array}$ & $F$ & $\operatorname{Pr}>\mathrm{F}$ \\
\hline A1 & 0.5014 & 0.5042 & 0.0102 & 0.000277 & 0.0003 & 0.024 & 0.9763 \\
\hline $\mathrm{A} 2$ & 0.0672 & 0.0663 & 0.0156 & 0.036250 & 0.0376 & 32,535 & $0.0410^{*}$ \\
\hline $\mathrm{A} 3$ & 0.0384 & 0.0375 & 0.0112 & 0.056944 & 0.0604 & 52,231 & $0.0063^{\star \star}$ \\
\hline A4 & 0.0545 & 0.0530 & 0.0168 & 0.063510 & 0.0678 & 58,661 & $0.0034^{\star \star}$ \\
\hline A5 & 0.1355 & 0.135 & 0.0228 & 0.019018 & 0.0194 & 1,677 & 0.1900 \\
\hline$A 6$ & 0.0876 & 0.0865 & 0.0202 & 0.035616 & 0.0369 & 31,946 & $0.0434^{*}$ \\
\hline B1 & 0.1414 & 0.1407 & 0.0250 & 0.020926 & 0.0214 & 18,488 & 0.1605 \\
\hline B3 & 0.0403 & 0.0364 & 0.0217 & 0.193285 & 0.2396 & 207,249 & $0.0001^{\star *}$ \\
\hline B4 & 0.0364 & 0.0355 & 0.0109 & 0.060591 & 0.0645 & 55,791 & $0.0045^{\star \star}$ \\
\hline B5 & 0.0516 & 0.0511 & 0.0112 & 0.031678 & 0.0327 & 28,298 & 30.0618 \\
\hline B6 & 0.0586 & 0.0574 & 0.0161 & 0.050846 & 0.0536 & 46,338 & $30.0110^{*}$ \\
\hline $\mathrm{C} 1$ & 0.0611 & 0.0582 & 0.0242 & 0.105310 & 0.1177 & 101,815 & $0.0001^{\star *}$ \\
\hline C3 & 0.0591 & 0.0568 & 0.0212 & 0.086489 & 0.0947 & 81,896 & 0.0004 \\
\hline $\mathrm{C} 4$ & 0.0607 & 0.0607 & 0.0081 & 0.011912 & 0.0121 & 10,428 & 80.3547 \\
\hline C5 & 0.0459 & 0.0455 & 0.0095 & 0.028541 & 0.0294 & 25,414 & 40.0817 \\
\hline C6 & 0.0660 & 0.0650 & 0.0169 & 0.043284 & 0.0452 & 39,134 & $40.0218^{\star}$ \\
\hline D1 & 0.0723 & 0.0698 & 0.0245 & 0.077006 & 0.0834 & 72,167 & $70.0010^{* *}$ \\
\hline D3 & 0.0393 & 0.0391 & 0.0069 & 0.020458 & 0.0209 & 18,066 & 60.1673 \\
\hline D4 & 0.0521 & 0.0517 & 0.0104 & 0.026558 & 0.0273 & 2.36 & 60.0975 \\
\hline D5 & 0.0320 & 0.0319 & 0.0046 & 0.013893 & 0.0141 & 12,187 & 70.2981 \\
\hline D6 & 0.0477 & 0.0473 & 0.0103 & 0.031196 & 0.0322 & 27,853 & 30.0645 \\
\hline
\end{tabular}

* Berbeda nyata ** Berbeda sangat nyata significant different ${ }^{*}(P<0.05){ }^{\star *}(P<0.01)$

Pengelompokan dari 3 populasi yang berbeda tersebut (Gambar 2) memperlihatkan bahwa tidak ada pemisahan yang nyata antar semua populasi.

Kedekatan (keeratan) kelompok daerah ditunjukkan oleh daerah himpitan antar daerah sampel (Suparyanto et al., 1999). Dengan demikian keeratan hubungan antara Sungai Musi dan Sungai Citanduy lebih kecil dibanding dengan keeratan Sungai Citanduy-Kapuas. Akan tetapi populasi Musi dapat menyatukan kedua populasi terpisah tersebut. Keeratan semua komponen antar tiga populasi yang diamati akan lebih nyata dengan menggunakan sharing component fenotip antar daerah sampel (Tabel 3).

Pendugaan sharing component atau dengan kata lain nilai kesamaan (index of similarity) antar kelompok dilakukan dengan menggunakan hasil analisis diskriminan berdasarkan kesamaan ukuran tubuh tertentu (Suparyanto et al., 1999). Hal ini dapat diartikan bahwa bagian tubuh tertentu perkembangannya tidak dipengaruhi oleh lingkungan di mana udang galah tersebut hidup, sedangkan beberapa ukuran tubuh lainnya berkembang sesuai dengan stress lingkungan di tempat hidupnya. Hal ini merupakan indikasi bahwa di setiap daerah, variabel tertentu tumbuh dalam laju yang berbeda yang dipengaruhi oleh faktor lingkungan. Dalam hal ini persamaan ukuran variabel (organ) merupakan gejala percampuran (sharing component) antar masingmasing daerah melalui percampuran gen masa lalu. Atau dengan kata lain, sharing componentmerupakan daerah konservasi gen yang dipertahankan oleh semua populasi walau habitatnya berbeda.

Nilai kesamaan ukuran tubuh (Tabel 3) memberikan penjelasan adanya percampuran yang terukur antara populasi satu dengan lainnya atau komponen tersebut merupakan suatu trait yang dipertahankan atau yang dibagikan sewaktu terjadi aliran gen (gene flow). Kesamaan ukuran tubuh dalam kelompok yang paling besar dalam populasi adalah pada populasi Musi $(73,21 \%)$; dan di antara populasi adalah $16,07 \%$ sharing dengan populasi Kapuas, dan sharing dengan Sungai Citanduy sebesar $10,72 \%$. 


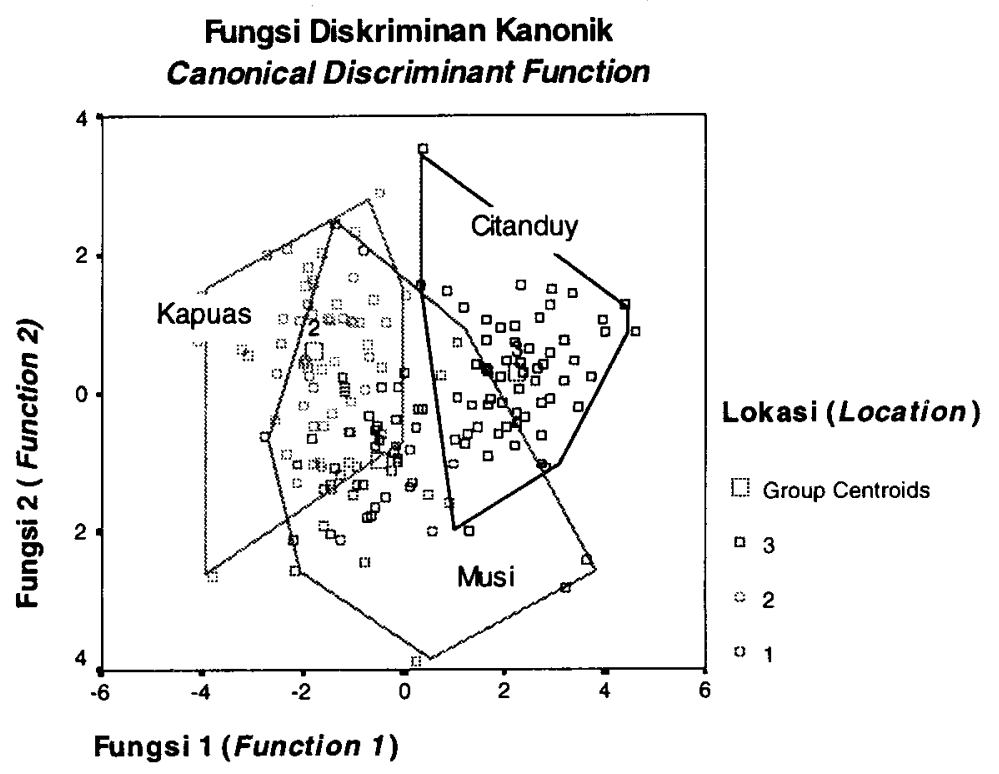

Gambar 2. Distribusi populasi udang galah tiga lokasi sampel berdasarkan pengamatan morfometrik dengan menggunakan analisis PCA

Figure 2. Population distribution of giant freshwater prawn from three different sample location characterized by morphometric observation analyzed by PCA

Tabel 3. Nilai percampuran fenotip dalam dan antar populasi (\%) udang galah yang menunjukkan sharing component antar populasi atau jalur transfer induk

Table 3. The value of phenotypic mixing inter and intra populations (\%) giant fresh-water prawn which showed a sharing component between population or the line of stock transfer

\begin{tabular}{llccc}
\hline \multicolumn{1}{c}{ Dari Lokasi } & Musi & Kapuas & Citanduy & Total \\
\hline Musi & 73.21 & 16.07 & 10.72 & 100.00 \\
Kapuas & 26.67 & 68.33 & 5.00 & 100.00 \\
Citanduy & 6.67 & 3.33 & 90.00 & 100.00 \\
Percent & 34.66 & 29.55 & 35.80 & 100.00 \\
\hline
\end{tabular}

Tabel 4. Matrik jarak genetik antar kelompok daerah sampel yang menunjukkan hubungan kekerabatan antar populasi udang galah

Table 4. Matrix of genetic distance of different sample location to show the relatedness between populations of giant freshwater prawn

\begin{tabular}{lccc}
\hline Daerah sampel & Musi & Kapuas & Citanduy \\
\hline Musi & 0 & 397,045 & 878,814 \\
Kapuas & 397,045 & 0 & $1,655,688$ \\
Citanduy & 878,814 & $1,655,688$ & 0 \\
\hline
\end{tabular}

Keragaman di dalam populasi Kapuas adalah sebesar $68,33 \%$; sedangkan sharing dengan populasi Musi sebesar $26,67 \%$; dan sharing dengan populasi Sungai Citanduy adalah $5,00 \%$. Populasi Sungai Citanduy mempunyai keragaman dalam populasi sebesar $90,00 \%$; dan membagi dengan populasi Musi sebesar $6,67 \%$; serta dengan populasi Kapuas $3,33 \%$.
Pengelompokan komponen tersebut masih terbatas pada trait yang diamati, oleh karena itu semakin banyak trait yang diamati akan semakin bagus gambarannya. Dengan demikian perlu memperlengkapi dengan karakter lain yang lebih komplit untuk mendukung kesempurnaan posisi masing-masing populasi di dalam persilangannya. 


\section{Jarak Genetik antar Kelompok Populasi}

Pada Tabel 4 terlihat matriks jarak genetik yang dihitung berdasarkan Suparyanto et al. (1999) dengan menggunakan prinsip Nei (1987) dan Manly (1989), dan yang digunakan untuk membuat pohon fenogram Gambar 3 (Suparyanto et al., 1999).

Dari Tabel 4 dan Gambar 3 terlihat bahwa jarak genetik terkecil dimiliki antara populasi Musi-Kapuas (dengan nilai 3,97045 ) dan diikuti selanjutnya oleh kelompok Musi-Citanduy (dengan nilai 8,78814 ) dan yang terbesar adalah antara populasi KapuasCitanduy (dengan nilai 16,55688).

Implikasi dari nilai tersebut adalah untuk persilangan antar populasi, jika perkawinan dilakukan component di dalam masing-masing populasi ialah Sungai Citanduy sebesar $90 \%$; pada populasi Musi $73,21 \%$; dan Kapuas $68,33 \%$.

\section{DAFTAR PUSTAKA}

Bookstein, F.L., B. Chemoff, R.L. Elder, J.M. Humphries, G.R. Smith, and R.E. Strauss. 1985. Morphometric in Evaluationary Biology. Braun-Braumfield Inc. Ann. Arbor, Michigan. $277 \mathrm{pp}$.

Cataudella, S., L. Sola, M. Corti, R. Arcangeli, G. La Rosa, M. Mattcp6la, M.C. Sbordoni, and V. Sbordoni. 1987. Cytogenic, genetic, and morphometric characterization of groups of common carp, Cyprinus carpio Vol. I. Proc. World Symp. On Selection, Hybridization, and Genetic Engineering in Aquaculture, Bordeaux, Berlin.

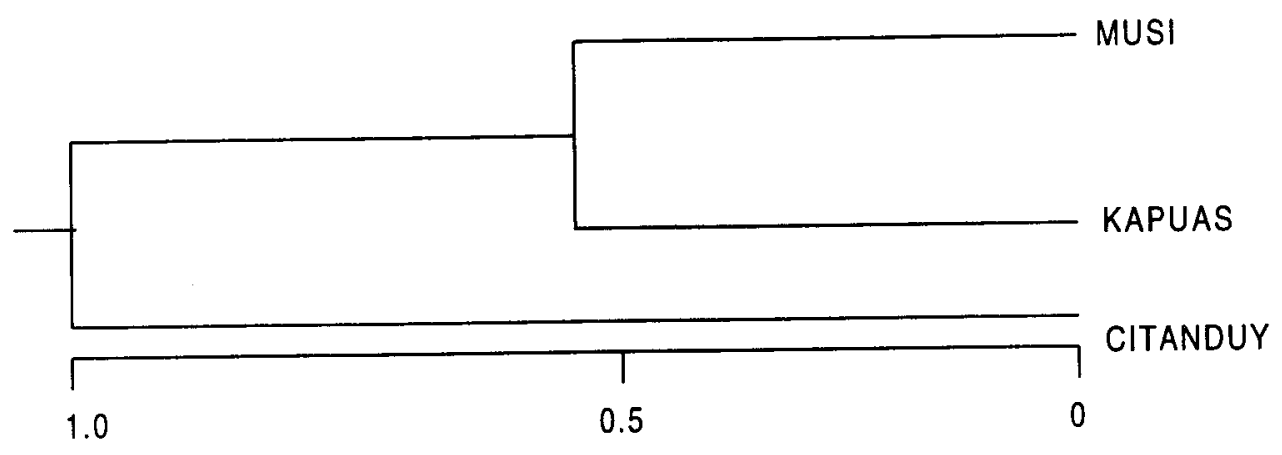

Gambar 3. Dendogram dari jarak genetik udang galah antara populasi Musi, Kapuas, dan Citanduy dengan menggunakan matrik jarak genetik (Tabel 4)

Figure 3. Dendogram of the genetic distance population of giant freshwater prawn from Musi, Kapuas, and Citanduy resulted fron (Table 4)

antara Kapuas $x$ Citanduy atau antara Musi $x$ Citanduy, dapat diduga akan meningkatkan keragaan secara nyata dibanding antara Musi x Kapuas (Tabel 4). Hal ini dikarenakan heterosis antara Musi $x$ Kapuas hanya berasal dari kelompoknya saja, sedangkan untuk kekerabatan yang jauh, keragaman diperoleh dari keduanya (Suparyanto et al., 1999).

\section{KESIMPULAN}

Terdapat perbedaan genetik antar populasi udang galah yang diambil dari 3 habitat asli. Jarak genetik terbesar dalam dendogram adalah antara populasi Sungai Citanduy dan Kapuas $(16,556)$, terendah adalah antara Musi dan Kapuas $(3,970)$, sedangkan antara Musi dan Sungai Citanduy adalah sebesar 8.788. Gambaran kekerabatan antar populasi berdasarkan PCA, populasi Kapuas terpisah dari Sungai Citanduy, tetapi keduanya disatukan oleh populasi Musi melalui sharing component antar komponen pada ketiga populasi tersebut. Sharing
Eknath, A.E., J.M. Macaranas, L.Q. Agustin, R.R. Velasco, M.C.A. Ablan, M.J.R. Pante, R.S.V. Pullin. 1991. Biochemical and morphometric approaches to characterize farmed tilapias. ICLARM Quarterly Report, Manila. 14(2):7-9.

Hadie, W. 1997. Studi Morfometrik dan Keragaman Genetika pada Populasi Ikan Lele (Clarias batrachus) di Sungai Musi dan Bengawan Solo. Thesis Universitas Indonesia. $32 \mathrm{pp}$.

Humphries, J.M., F.L. Bookstein, B. Chemoff, G.R. Smith, R.L. Elder, and S.G. Poss. 1981. Multivariste discrimination by shape in relation to size. Syst. Zool. 30:291308.

Malecha, S.R., P.A. Nevin, P. Ha, L.E. Barcj, Y. LamadridRosa, S. Musano, and D. Hedgecock. 1982. Sex-ratio and Sex-determination in progeny from crosses of surgically sex-reversed freshwater prawns, Macrobrachium rosenbergii. Aquaculture. 105:201218.

Matricia, T. 1990. Body shape differences between two populations of Indonesian common carp (Cyprinus carpio) mutlivariate morphometric analysis. Prog. 
Rep. The International Development Research Center Canada, AARD, RIFF, Indonesia. 139-161.

Manly, B.F. 1989. Multivariate Statistical Methods. A Primer. Chapman and Hall, London. 159 pp.

McGlade, J.M. and E. Boulding.1985. The truss: A geometric and statistical approach to the analysis of form in fishes. Can. Tech. Rep. Fish. Aquacult. Sci. No. 147.

Nei, M. 1987. Moleculer Evolutionary Genetic. Columbia University Press, New York USA. 512 pp.

Sprent, P. 1972. The matematics of size and shape. Biometrics. 28:23-37.
Strauss, R.E. 1980. Genetic and morphometric variation and systematic relationships of eastern North American Sculpins (Pisces:Cottidae). In Bookstein et al., 1985. Morphometric and Evolutionary Biology. Braun-Brufield In. Ann. Arbror, Michigan. 277 pp.

Suparyanto, A., T. Purwadaria, dan Subandriyo. 1999. Pendugaan jarak genetik dan faktor peubah pembeda bangsa dan kelompok domba di Indonesia melalui pendekatan analisis morfologi. Jurnal IImu Ternak dan Veteriner. (4): 80-87. 